\title{
CBME 2017 Gender Equalities on the Czech Labor Market in Comparison with EU
}

\author{
Katerina Legnerova \\ Faculty of Business Administration, University of Economics, Prague, Czech Republic \\ E-mail: katerina.legnerova@vse.cz
}

Received 13 February 2017; accepted 11 April 2017

\begin{abstract}
The paper deals with the equality of women and men in the labor market in the Czech Republic compared with the European Union in connection with the strategy for the period 2010-2015. The aim of the research was based on analysis of available statistical data to describe and assess the evolution of the situation in this area in the last five years, assess the benefits of the Strategy and to assess the achievement of the objectives that the European Commission has identified. Data is processed and analysed from the perspective of the whole of the European Union, with a focus on the Czech Republic. Based on the analysis of available statistical data, and through selected indicators described the current situation in selected areas of the issue of the achievement of the equality between women and men in the Czech labor market. The obtained data are compared to the data from 2009 and by the method of induction is evaluated the achievement of the rate of equality between women and men in the labor market and also the contribution and the rate of implementation of the strategy, the primary objective is mentioned in all areas to achieve this equality.
\end{abstract}

Keywords: Labor Market, Gender Equality, European Union.

JEL Classification: J08, M12, M38.

Conference topic: Modern Business Management Problems and Perspectives.

\section{Introduction}

The objectives of the paper are to compare the equality of men and women on the labor market in the European Union and in the Czech Republic, and to determine the trends in gender labor market. The paper is based on the secondary research in the area of gender diversity. It compares the position of the Czech Republic in the gender issue between 2010 and 2015 using the data available online.

Achieving gender equality, a situation in which the social and cultural environment recognizes both men and women as being of equal value is a desirable goal from a social justice perspective (Dilli et al. 2015). The general equality between people, including equality between women and men, should be one of the fundamental rights of every human being. Equality between women and men means that they have both sex's equal rights and opportunities, across all social sectors, which, however, in spite of the long-term progress in the society is still not the rule. For that reason, the European Union determined the equality between women and men as one of its fundamental values.

In the first paragraph is described the gender issue in the labor market. It involves the main reasons for differences such as education, the number of children or age. Further the article copes with the situation in the European Union (futher EU) in the gender topic in labor market. EU involved the topic into the strategy for the period 2010-2015. The last part of the paper is oriented to the situation in the Czech Republic. It deals with the number of employed women, women in entrepreneurship, in managerial positions and in the Governments and Parlaments. A separately part is devoted to the salary differences according to gender. Discusion and conclusion of the research topic contain the evaluation of the EU policies in the area of gender equality in the labor market.

\section{Gender equality}

Efforts to apply the principles of equal opportunities for men and women to a large extent became a public issue. Especially in the last two decades after joining the Czech Republic to the European Union. The importance of the principle of the new awareness of equal opportunities gradually takes the idea about the fulfilment of equal rights for men and women on all levels of the society and the economy. The EU within the framework of its policy to promote

(C) 2017 K. Legnerova. Published by VGTU Press. This is an open-access article distributed under the terms of the Creative Commons Attribution (CC BY 4.0) License, which permits unrestricted use, distribution, and reproduction in any medium, provided the original author and source are credited. 
equality between men and women became more and more important. One of the fundamental prerequisites for the achievement of the EU objectives in the field of employment, social solidarity and unity is the application of the equal access of men and women in the labor market. Wejnert and Rodriques (2015) thought if governments and policy makers create gender-sensitive policies and programs that aim at enhancement and protection of women's rights, economic empowerment and improvement of women's well-being, and hence citizens of the global world embrace gender equality in everyday practices. The most developed country in gender equality is Sweden. The Swedish political goal of gender equality is closely connected to family policy and some reforms (Almqvist, Duvander 2014). According to Annesley et al. (2015) increasing women's representation in politics has positive impacts on political attention regarding gender equality issues, gendering policy debates and promoting women-friendly policy outcomes. Grown et al. (2016) mentioned that quotas can be a proven tool to increase female representation in political bodies. But it still so not solve the gender problem. Other tools can support the gender balance decision-making, like career planning, coaching, training and support for women (Krook, Norris 2014). Morrison (2015) suggests to include the gender topic into the teaching at business universities. It can help to develop more women enterpreneurs or managers.

The topic is very hot, but we have to take into consideration the historical roots of the inequality. The female workforce is shaped by choice of education and occupation, career development possibilities, the quality of working conditions and the attractiveness of the net wages for work compared to social benefits. When deciding women or members of her family, what education to achieve and what job she wants to apply, how-ever, to take into account other than economic considerations. If the employer prefers work force because of sex, race, disability or age, etc. certain education, aims to acquire professions and to get a job from a limited circuit of employment. Segregation into occupations or employment is referred to as horizontal. Usually, it accompanies the concentration of work in a particular sector, for example, a study on the secondary medical school intended for the work of nurses in health and social care sector in the public sector. Horizontal segregation to the profession becomes one of the causes of the differences in wages between men and women with visible differences (Anker 1998). The feminisation is characterized by the circumstances such as lower salary, the lower prestige of the employment or little interest of men in the profession or the whole sector. The problem of vertical segmentation is the concentration of women in lower positions and men in senior jobs, where they have greater competence and responsibility, and often work in leadership positions in areas otherwise typical for women. Gender segmentation represents many disadvantages for both sexes, but especially for women. Feminized jobs or sectors are less attractive regarding the lower wages, are considered boring and monotonous, assume lower qualifications or intelligence than male and are considered less prestigious. Also, the vertical segmentation continually persists despite the fact that the level of women's education is steadily increasing. Inequality in access to employment gender stereotypes represents a significant role in the decision-making of managers in the recruitment of new staff. In addition to differentiation of female and male jobs employers are afraid of the conflict of family and work responsibilities of women.

Women need more than men to reconcile their work, personal and family life, since caring for a home and children. They often interrupt the career or seeking such a mode of working time, which will allow them to go to work and take care of the family. This issue limits their opportunities gradually accumulate work experience, such as have men. In effect, this means that women do not have sufficient professional experience and fails to meet one of the requirements for promotion to the higher and senior positions. We are talking about vertical segregation. Also, women are at a disadvantage in the labor market and the fact that employers have for them by legislation to create and improve the working environment, for example, sanitary facilities for women, to allow part-time work or flexible working hours, or home work. "Part-time work is often seen as a manifestation of the pressure on women to accommodate care and reconcile work and family life" (Orloff 2002). According to Sparreboom (2014) Occupational segregation by sex is a major obstacle to equality in the workplace, and incurs social and economic costs for individuals, firms and society at large. According to Goldin (2014), the employment gap is closely connected with age and education. Higher age and lower education of women can cause the main differences in employment, achieved managerial position and the higher salary. But it is necessary to mention also the glass ceiling that does not allow women to grow to the higher position. Hymowitz and Schelhardt named the invisible barriers between women and senior management position as "Glass Ceiling" in 1986 (Frazier 2005; Cook, Glass 2014). Many studies confirmed that the presence of women in managerial positions improved firm value, innovation, social responsibility and also financial results (Desvaux et al. 2007; Chisholm-Burns et al. 2017). Fehre et al. (2014) confirmed that women representation in leading positions improve the level of communication within the organisation. It is at the same time the positive signal to other women co-workers (Lindstädt 2011). Women have the potential to make a unique contribution to decision making in organizations and that organizations are better off when their voices are heard so tackling this problem matters (Pawliw-Fry 2016).

The situation on the political scene is similar to the managerial position. People, that vote, are under the impact of stereotypes when deciding whether to support a woman candidate, often with negative consequences for that woman (Dolan 2014). Men are considered as more powerful and more decisive and stronger than women (Lawless, Fox 2010; Murakami 2008). 


\section{Situation in the European Union}

Equality between women and men is one of the core principles on which the European Union is founded. The European Commission has been trying to improve the status of women not only in the labor market but the society in General. Although this effort brings significant results and progress in this area over time, striking, about real equality in the majority of Member States are still not talking. In 2010, the European Commission adopted a Strategy for equality between women and men 2010-2015, further Strategy in which it undertakes to carry out appropriate measures to improve the situation in this area. The European Commission (2011) in this strategy divides the issues of (in) equality between women and men in six key areas:

- Equal economic independence for women and men

- Equal pay - equal pay for equal or comparable work

- Equality in decision making

- Dignity and prevent violence against women

- Equality between women and men in the framework of external actions

- Horizontal issues.

The difference in the employment of women and men was in 2009 according to the statistics the European Commission strategy for the next period stated even in developed European countries still considerable. The average women's employment in the European Union was seen in employment and $62.3 \%$ of men, which in the same year amounted to an average of $75.7 \%$, were thus more than a $13 \%$ lower. The biggest difference in the employment of men and women this year was recorded in the Republic of Malta, alarming 37.5\% (40.0\% women, men 77.5\%). In contrast, the smallest differences we can observe in the Baltic States. In Lithuania even women exceed men about $0.4 \%$ of employment. The Czech Republic was placed in this comparison with below-average, the difference $18.8 \%(61.4 \%$ women, men $80.2 \%$ ) was the fourth largest.

The involvement of an increasing number of women in the workforce works as a corrective to the decreasing share of the working-age population, thereby reducing the strain on public finances and social security system (European Commission 2011). The biggest problem in this area is the very low employment of older women, single mothers, women with disabilities, and the restrictions of women belonging to ethnic minorities. The difference in the employment of women and men belonging to these disadvantaged groups of the population is usually much larger and has more serious impacts (European Commission 2011). The influence of the difference in the employment of women and men has of course also parenting, since women still carry a much greater share of the responsibility connected with family matters. A considerable part of women still feel they need in life to choose between family and career, and paternity leave remains even today very exceptional, sometimes even of outrage around. The proportion of women entrepreneurs is also very low.

Discrimination against women in the labor market and economic discrimination can be defined as a situation where women with the same skills, training and experience and the same productivity at work as men receive lower wages. They may also be a subject to different conditions and different opportunities are offered to them in the labor market.

By this definition we can define four types of discrimination against women in the labor market:

- Wage discrimination: women receive a lower wage than men by the same productivity

- Employment discrimination: organizations prefer hiring workers men (even though they are as productive as women) and as a result, women are faced a higher rate of unemployment

- Professional discrimination: women have more difficult or completely impossible entry into certain professions, known for typically as men professions, and vice versa women are pushed into the other, typically "female" jobs.

-Discrimination in access to human capital: worse access for women to education and other opportunities increasing productivity.

The first three types are referred to as discrimination, a fourth type, by contrast, is called indirect discrimination (premarket discrimination), because her man meets before he finds himself in the labor market. We can also add another type of discrimination which is called the "glass ceiling". The glass ceiling refers to a situation where opportunities for advancement in a career are limited because of sex, race, or in general due to membership of a particular group of the population (OECD 2012). In other words, therefore, the "glass ceiling" is an invisible barrier that prevents women in the procedure after the career ladder toward the top positions.

Although the principle of equal remuneration for women and men for equal work or work of comparable value enshrined in the treaties of the European Union on average, men still earn more than women. The Gender Pay Gap (GPG) remains constant as a percentage of the difference between averages gross an hourly wage of employed men and women.

A measure of economic independence is in most cases directly related to the participation in the labor market. A pointer to the employment of women and men in this area is therefore of great value, which is well aware of the European Commission. EU Commission defined this topic as one of the top five objectives in its vision. The Europe 2020 has identified the overall average employment at the level of $75 \%$. To achieve this objective, it is necessary, 
however, to significantly increase the rate of employment of disadvantaged groups, such as older people, migrants and or just women.

On average, across the European countries, there was a quite noticeable settlement of employment of women and men, as in women occurred between 2009 and 2014 in about $1.5 \%$ of the increase in employment, while in men, there was a very slight drop ( $0.3 \%)$. Overall, in the years 2009 to 2012 could be seen a small decrease in employment due to the economic crisis. The crisis occurred in 2009 , but its impact on employment and unemployment statistics we could see in the next years. In the years 2013 and 2014 employment overall grew again.

A decrease in the difference between the employment of men and women we can see in the most EU Member States. The average value of this indicator throughout the European Union (including Croatia) decreased during the reporting period by $1.8 \%(13.4 \%$ to $11.6 \%)$. The most striking change was recorded in Greece, but which, despite the decline of $25.6 \%$ to $17.6 \%$ difference shows still the third worst value and inequality between women and men in this field European standards very high. In the other two states with the worst results, Malta and Italy, there was also a significant decrease in either the difference ( $7.4 \%$ of Malta and Italy about $4.8 \%)$, which is very positive. If the trend of recent years will continue and women's employment in those States will grow at its current pace continues, could Greece, Italy and even Malta very realistically by 2020 to zoom, or even settle to the other EU States.

For these, of course, is also more than a 7\% decline in Cyprus and Finland. The Czech Republic is also one of the States where there has been a decline in the value of this indicator and, therefore, to improve the situation. A decrease of $2 \%$ is not a breakthrough, but it is a move in the right direction. If we look at the evolution of the situation in more detail, yet we find that in 2010 had this pointer for the Czech Republic 18.7\% value, in $201118.2 \%$ in 2012 $17.7 \%, 17.2 \%$ in a year and at the end of a 24 -year 2014 resulting $16.8 \%$. From these data, it is evident that the pace of decline in this indicator has recently considerably increased, and in the following years, we might expect significantly better results.

In the overall scale of the difference between the employment of men and women, which can be perceived positively, but to achieve the $75 \%$ of total employment by 2020 should be the rate of growth of employment of women and other disadvantaged groups of the population continue to increase.

\section{Situation in the Czech Republic}

The Czech Republic began to deal more intensively with the issue of gender equality in 1990, though his affec-tion for the solution of the problems of discrimination expressed on 17. July 1980, when the then Czechoslovak Socialist Republic signed the Convention on the Elimination of all forms of discrimination against women in Copenhagen. There was set the legislation of the principle of equality in the labor market. The types of discrimination in employment were defined and also set up the possibility of punishment for the violation of equal treatment for women in 1990. Since that time the new law was defined, especially the equal opportunities for all employees in the Czech Labor Code in 2006 and the Antidiscrimination law in 2009.

For the description of actual gender situation in the labor market were chosen five indicators. There are employed women, women as entrepreneurs, women in the top managerial positions, women in government and parliament and the gender pay gap.

\section{Women employment and unemployment}

The index of the total employment of the Czech population increased in both categories (men/women). The women employment is growing more quickly. The unemployment rate showed the significant difference in gender; the trend has no significant improvement in women unemployment.

Table 1. Employment and unemployment of men and women in the Czech Republic (\%) (Source: Eurostat)

\begin{tabular}{ccccc}
\hline & \multicolumn{2}{c}{ Employment } & \multicolumn{2}{c}{ Unemployment } \\
\hline & Men & Women & Men & Women \\
\hline 2010 & 63,7 & 45,1 & 6,4 & 8,5 \\
2011 & 63,7 & 45,6 & 5,8 & 7,9 \\
2012 & 63,6 & 45,9 & 6,0 & 8,2 \\
2013 & 64,1 & 46,7 & 5,9 & 8,3 \\
2014 & 64,1 & 47,1 & 5,1 & 7,4 \\
2015 & 65,0 & 48,1 & 4,2 & 6,1 \\
\hline
\end{tabular}

The Czech Republic supports significantly the parental leave. Parental leave is still almost exclusively in the Czech Republic the dominant women, although the proportion of men was slightly increasing. In 2012, in the Czech Republic receive parental allowance 5249301163 thousand women and men, which means the equivalent of only $1.7 \%$ of men. 
In the Czech Republic is the option to choose up to 4 years ' full-time parent, i.e., the longest parental compared with EU countries.

Only about half of the women return after their parent to the original employer. The survey of employment and care for small children showed that approximately $54 \%$ of women had an interest in the return to the previous employer. $34 \%$ of the original job, $37 \%$ preferred employment with another employer, $6 \%$ of these women wanted to begin or continue in a private business, and only $3 \%$ did not want to return. $14 \%$ of the respondents reported as a reason for seeking a different solution than returning to the original employer, the employers ' discriminatory behavior. Motherhood and parenthood cause that women in the Czech Republic leave the company for several years leave, which has an adverse impact on their qualifications and the subsequent application of the labor market. An earlier return for them is often not possible due to lack of places in childcare facilities, missing part-time jobs, or even discrimination from the employer.

\section{Women entrepreneurship}

The percentage of women entrepreneurship is nearly stable. If we look at the situation in the Czech Republic, we find that its development of employment women and men still does not move in the same direction, as well as in most other States. There was relatively stable growth between 2009 and 2012, but then it decreased. In the top 10 companies in 2014 only $10 \%$ of owners represented women (Legnerova 2015).

Table 2. The percentage of women entrepreneurs in the Czech Republic (Source: Eurostat)

\begin{tabular}{cc}
\hline Year & Percentage \\
\hline 2009 & 27,6 \\
2010 & 28,4 \\
2011 & 28,9 \\
2012 & 30,7 \\
2013 & 29,7 \\
2014 & 28,9 \\
\hline
\end{tabular}

The effort of the European Union and other bodies supporting women in entering the business in the period was significantly affected by the economic crisis. Many people (not just women) has sparked fear and concern from selfemployment on the one hand, on the other hand, however, the loss of a job, due to the economic crisis, could have many people to a separate business.

\section{Women in the top managerial positions}

The average value of on fifth representation of women on the top boards of the largest companies quoted on the stock exchange, of course, is far from satisfactory, but the pace to that situation in the European Union in recent years, in my opinion, adequate. The highest growth $(22 \%)$ has occurred in France, which is in this together with Latvia got to head across the EU; both countries described the proportion of women at the level of $32 \%$. The value of this indicator is thus in France more than tripled. Other countries in which there has been significant increase in this indicator are Italy (an increase of 20\%), Latvia (already mentioned by 15\%), Belgium (14\%), United Kingdom (12\%), Germany (11\%), the Netherlands, Austria and Slovenia (for all three of the latter increased by $10 \%$ ).

The Czech Republic in 2009 with their values ranged above the EU average but fell below it. The decline in the proportion of women in top management bodies of tracked by from $13 \%$ to $4 \%$ ranked our Republic on the penultimate position; the situation is worse in Malta only (but low-value shows the long term). This marked decline in this indicator has been in over the last year and a half, since even in April 2013, this value was at the level of 18\%. In October 2013, it then was 11\%, $20147 \%$ in April and in October 2014, the already mentioned 4\%. Any objective reason for this decline could not be traced. The representation of women should be increased following the adoption of the European Directive regulating this issue; the proposal provides for the establishment of at least $40 \%$ of the share of women in non-Executive (non-executive) the bodies listed companies in 3-5 years. If we look at the statistics on the representation of each gender on the position at the head of the peak of the managing authority (president of the board) tracked by the company, in a positive sense of the word slightly protrude only values of Poland, where women occupy more than a quarter of such positions.

A better situation is in the managerial positions in large companies not quoted on the stock market. Women are most commonly employed in the human resource (79\%), and with a strong detachment in finance (44\%) and marketing (41\%). Also in these fields for the last years, most women strengthened their position. While in 2009 on the position of HR manager worked $57 \%$ of women, there were $79 \%$ in 2014 . A similar trend can be observed in finance and marketing. Women Financial Director currently has $44 \%$ of the largest Czech companies, compared with $28 \%$ in 2009 . Similarly, in 2009, a quarter of the Marketing Department of the biggest Czech companies was led by a woman, six years later, however, has led the marketing woman $41 \%$ of enterprises. In the last year, between the years 2013 and 
2014, women gradually began to replace men from the seats of business directors. The proportion of women in place of trade manager grew by more than 3\% from 14\% in 2013 to $17 \%$ in 2014 . According to Adams and Funk (2012) it is possible that women must be like men to break the glass ceiling.

The same is in the situation of woman in academic and scientific positions (Goodman, Nosengo 2003).

Table 3. The percentage of women in Managerial Positions in the Czech Republic (\%) (Source: Eurostat)

\begin{tabular}{ccccccc}
\hline & 2009 & 2010 & 2011 & 2012 & 2013 & 2014 \\
\hline Finance & 28,23 & 31,13 & 34,82 & 45,17 & 42,35 & 44,04 \\
IT & 5,97 & 5,09 & 4,26 & 3,16 & 3,12 & 3,28 \\
Marketing & 25,47 & 33,27 & 37,15 & 41,64 & 40,98 & 40,72 \\
Obchod & 13,02 & 12,1 & 11,72 & 15,91 & 13,79 & 17,06 \\
HR & 57,11 & 64,69 & 69,87 & 79,34 & 78,47 & 79,46 \\
Top Management & 3,83 & 4,71 & 4,97 & 5,51 & 5,04 & 6,14 \\
\hline
\end{tabular}

\section{Women in the Governments and Parliaments}

In the area of national Governments and Parliaments in general, not so significant shift, as was the case with the representation of women in the management of listed companies on the stock exchange, but still there is the resulting proportion of women still higher. The average value of this indicator for the entire European Un-ion for representation in the Government has shifted from $27 \%$ to $28 \%$, which is almost negligible. In absolute terms, this throughout the EU means five women Ministers. In the long term, the highest values (around 60\%) shows Finland in which the situation during the reporting period also has not changed much. Very satisfactory values at the level of 40-50\% representation of women in national Governments by the end of 2014 can be observed in Sweden (50\%), France (47\%), Estonia (43\%), Italy (41\%) and Slovenia (40\%).

In 2009, the Czech Republic had a total of 22 members, 4 of them women (18\%), at the end of 2014, then a total of 21 members, including five women (24\%) in Government (see Table 2). For comparison, there are all data from 1992. We know that in the last ten years is the situation developing much more positively.

Table 4. The percentage of women in Government in the Czech Republic (Source: Eurostat)

\begin{tabular}{cccc}
\hline Years & Total Number & Women & Percentage \\
\hline $1992-1996$ & 25 & 0 & 0 \\
$1996-1998$ & 23 & 1 & 4,3 \\
$1998-2002$ & 27 & 0 & 0 \\
$2002-2004$ & 21 & 2 & 9,5 \\
$2004-2005$ & 18 & 2 & 11,1 \\
$2005-2006$ & 22 & 3 & 13,6 \\
$2006-2007$ & 15 & 2 & 13,3 \\
$2007-2009$ & 24 & 5 & 20,8 \\
$2009-2010 *$ & 21 & 4 & 19 \\
$2010-2013$ & 29 & 3 & 10,3 \\
$2013-$ till now & 21 & 5 & 2,8 \\
Total & 280 & 30 & 10,7 \\
\hline
\end{tabular}

\section{Equal pay}

This part of the paper focuses on the development of the General indicators of Gender Pay Gap (GPG), which provides information about the difference in the average wages of men and women, regardless of individual causes. The biggest increase was visible in Slovenia (4.1\%). The situation is alarming in Estonia, where the increase was a little smaller (about 3.3\%), but due to the long term, the worst values of GPG indicators Estonia attracted $30 \%$ gap between the average salary of men and women. An increase of more than $2 \%$ for this indicator was also recorded in Portugal (3\%) and Spain (2.6\%). On the contrary, the most notable improvement has occurred in the Czech Republic, where the value of GPG has decreased by $3.8 \%$ in 2012, then in 2014 only by $3.4 \%$. According to Khoreva (2011) the 
pay expectations can have an impact on the way individuals perceive the gender pay gap because individuals' perceptions of financial rewards of others are affected by the perceptions of whether their opportunities are equal to the opportunities of others.

Table 5. Gender pay gap in the Czech Republic (\%) (Source: Eurostat)

\begin{tabular}{l|l}
\hline 2009 & 25,9 \\
2010 & 21,6 \\
2011 & 22,6 \\
2012 & 22,1 \\
2013 & 22,3 \\
2014 & 22,5 \\
\hline
\end{tabular}

The decline in the average value of GPG in the CZ in six years is not a breakthrough, but it is a move for the better position of women. The development of the GPG indicator is volatile and unstable. The GPG, therefore, cannot confidently predict the future values. If, however, will keep at least slightly improving trend, Europe and also the Czech Republic will step by step approach the equality of pay for women and men in equal pay area.

If we compare the level of education in the years 2010 and 2015, the increase in the percentage of women with a university degree is significant. This trend can lead to decreasing of the gap in the difference of payment between men and women.

Table 6. Difference in level of education 2010-2015 in the Czech Republic (\%) (Source: Eurostat)

\begin{tabular}{lcc}
\hline \multicolumn{1}{c}{ Education: } & Women & Men \\
\hline Basic and without education & 74,5 & 95,7 \\
Secondary without A-level exam. & 99,2 & 93,3 \\
Secondary with A-level exam. & 96,5 & 105,1 \\
University & 147,8 & 124,7 \\
\hline
\end{tabular}

The situation in the Czech Republic is improving in all the researched areas. We can see positive development in women education, unemployment rate. But there is still issue with equal pay and glass ceiling.

\section{Conclusions}

Europe is going at present through many economic and social changes and gradual approximation to equality between women and men is one of them. Not only in the labor market, however, is but still many inequalities also remain and deal with them a formidable task, even for those with such a big field of competence, such as the European Union. The aim of the paper was based on selected indicators describe the evolution of this issue for the past five years, and thus to evaluate the benefits and objectives of recent European Commission initiatives targeted at the achievement of equality between women and men. This development can be described as positive since in all three areas has been pursued to improve the situation and to the gradual deletion of the differences and inequalities between women and men.

In the field of employment was reduced the gap between the work of men and women's employment, and more specifically from $13.4 \%$ in 2009 to $11.6 \%$ in 2014 . However, in this area not only to balance the values that show a gender-specific but also to compensate for the extent of the difference between individual States, since States showing significantly worst long term "Eurosceptic" and vice versa. The Czech Republic in this field indicates the value in the long term a shade worse than the EU average, the past few years, however, gives real hope that the Czech Republic the average values in the foreseeable future. Employment has been supplemented by an indicator showing the percentage of women among the self-employed, which has also noticed a slight shift in the meaning of convergence to equality between women and men in the labor market.

On this positive development has a significant impact the European Commission. It is necessary to mention that to achieve total employment at the level of $75 \%$ by 2020 (which is one of the key objectives of the Europe 2020 vision) it should be the rate of growth of employment of women, and other disadvantaged groups continue to increase. In the area of equal pay for women and men, which was demonstrated by an indicator of the Gender Pay Gap, there has been only a very slight improvement in the situation. The difference between the average hourly wages of men and women, between 2009 and 2013 to $17.2 \%$ decreased from $16.4 \%$. 
The Czech Republic in this area has considerably below average values, but in the period under review has seen the most dramatic improvement of the situation, thus very closer to the average. Let us hope, however, that Europe manages to keep at least the slowly improving condition. A pointer to the Gender Pay Gap has also added indicators of segregation of the labor market, which is in the area of equal pay positive influence. For these additional signs, however, was recorded totally opposite and unexpected result, since both of the selected indicators, there has been a deepening of inequalities between women and men.

European Commission initiative aimed at the Elimination of disparities in the salaries of men and women can be assessed active, targeted initiatives to support women to enter non-traditional occupations and for them, however, not the industry.

\section{Disclosure Statement}

I declare not to have any competing financial, professional, or personal interests from other parties.

\section{References}

Adams, R. B.; Funk, P. 2012. Beyond the glass ceiling: does gender matter?, Management Science 58(2): $219-235$. https://doi.org/10.1287/mnsc.1110.1452

Almqvist, A.; Duvander, A. 2014. Changes in gender equality? Swedish fathers' parental leave, division of childcare and housework, Journal of Family Studies 20(1): 19-27. https://doi.org/10.5172/jfs.2014.20.1.19

Anker, R. 1998. Gender and Jobs: sex segregation of occupations in the world. Geneva, ILO. International Labour Office.

Annesley, C.; Engeli, I.; Gains, F. 2015. The profile of gender equality issue attention in Western Europe, European Journal of Political Research 54(3): 525-542. https://doi.org/10.1111/1475-6765.12095

Cook, A.; Glass, C. 2014. Above the glass ceiling: when are women and racial/ethnic minorities promoted to CEO?, Strategic Management Journal 35(7): 1080-1089. https://doi.org/10.1002/smj.2161

Desvaux, G.; Devillard-Hoellinger, S.; Baumgarten, P. 2007. Women matter. Gender diversity, a corporate performance driver [online], [cited 23 March 2017]. Available from Internet: www. raeng.org.uk/publications/other/ women-matter-oct-2007

Dilli, S.; Rijmpma, A.; Carmichael, S. G. 2015. Achieving gender equality: development versus historical legacies, CESifo Economic Studies 61(1): 301-334. https://doi.org/10.1093/cesifo/ifu027

Dolan, K. 2014. Gender stereotypes, candidate evaluations, and voting for women candidates: What really matters?, Political Research Quarterly: 67(1): 96-107. https://doi.org/10.1177/1065912913487949

European Commission. 2011. Strategy for equality between women and men 2010-2015 [online], Luxembourg: Publications Office of the European Union, 2010. 40 s. [cited 23 March 2017]. Available from Internet: http://ec.europa.eu/justice/genderequality/files/strategy_equality_women_men_en.pdf/

Eurostat .... [online], [cited 23 March 2017]. Available from Internet: http://ec.europa.eu/eurostat/data/database

Fehre, K.; Lindstädt, H.; Picard, A. 2014. Förderung von frauen in führungspositionen: Bezugsrahmen und empirische analyse der unternehmerischen Maßnahmen, $\mathrm{Z} f b F(66)$ : 37-68.

Frazier, E. M. 2005. Glass ceiling: Factor myth. NAAAS Conference Proceedings. Scarborough, 1929-1948.

Goldin, C. 2014. A grand gender convergence: its last chapter, The American Economic Review 104(4): 1091-1119. https://doi.org/10.1257/aer.104.4.1091

Goodman, S.; Nosengo, N. 2003. Europe is pushing to get more women scientists into industry and academia, but can the commission legislate for gender equality?, Nature 426(6963): 210-211. https://doi.org/10.1038/nj6963-210a

Grown, C.; Addison, T.; Tarp, F. 2016. Aid for gender equality and development: lessons and challenges, Journal of International Development 28(3): 311-319. https://doi.org/10.1002/jid.3211

Chisholm-Burns, M. A.; Spivey, C. A.; Hagemann, T.; Josephson, M. A. 2017. Women in leadership and the bewildering glass ceiling, American Journal Of Health-System Pharmacy 74(5): 312-324. https://doi.org/10.2146/ajhp160930

Khoreva, V. 2011. Gender pay gap and its perceptions, Equality, Diversity and Inclusion: An International Journal 30(3): $233-248$. https://doi.org/10.1108/02610151111124969

Krook, M. L.; Norris, P. 2014. Beyond quotas: strategies to promote gender equality in elected office, Political Studies 62(1): $2-$ 20. https://doi.org/10.1111/1467-9248.12116

Lawless, J.; Fox, R. 2010. It still takes a candidate: why women don't run for office. New York: Cambridge University Press. https://doi.org/10.1017/CBO9780511778797

Legnerová, K. 2015. Generacni obmena ve vedeni podniku. Praha: Wolters Kluwer.

Lindstädt, H. 2011. Die andere Hälfte der Intelligenz nutzen, DIS AG Management Special 6: 2-3.

Morrison, J. L. 2015. Integrating gender equality into business and management education, Journal of Education for Business 90(7): 410-412. https://doi.org/10.1080/08832323.2015.1081867

Murakami, M. 2008. The power of identity: the consequences of party polarization for the attitudes and behaviors of the mass public. University of California Berkeley.

OECD. 2012. Closing the gender gap: act now. Paris: Organisation for Economic Co-operation and Development Publishing, 349. 
Legnerova, K. 2017. Gender equalities on the Czheck labor market in comparison with EU

Orloff, A. S. 2002. Women's employment and welfare regimes: globalization, export orientation and social policy in Europe and North America. Social Policy and Development Programme Paper No. 12 (June). Geneva: United Nations Research Institute for Social Development.

Pawliw-Fry, J. P. 2016. Women leaders, Leadership Excellence Essentials 33(12): 26.

Sparreboom, T. 2014. Gender equality, part-time work and segregation in Europe, International Labour Review 153(2): 245-268. https://doi.org/10.1111/j.1564-913X.2014.00203.x

Wejnert, B.; Rodriques, E. 2015. Enabling gender equality: future generations of the global world, Bingley Emerald Group Publishing Limited. 